\title{
上肢への血管柄付骨移植の経験
}

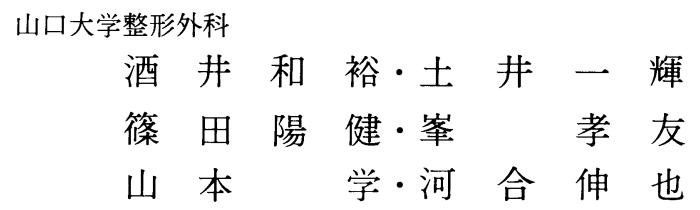

\section{Free Vascularized Bone Graft in the Upper Limb}

by

Kazuhiro Sakai, Kazuteru Doi, Kiyotake Shinoda, Takatomo Mine, Manabu Yamamoto and Shinya Kawai

Department of Orthopaedic Surgery,

Yamaguchi University School of Medicine

Five cases of free vascularized bone graft applied to upper limb reconstruction were studied. Three cases of pseudarthrosis of the humerus and a case of pyogenic arthritis of the elbow were treated with free vascularized fibula grafts. A case of giant cell tumor of the distal end of the radius was treated by wide resection and a free vascularized fibula head graft. Their results were satisfactory, and the bone unions were achieved within 3.5 months postoperatively in most of them. However, bone defects and recipient bone in the upper limb are of ten too small to use free vascularized fibula or iliac bone graft. In such a case, free vascularized metatarsal bone graft or free vascularized periosteal graft may be useful.

\section{はじめに}

近年マイクロサージャリーの発達により各種の遊離 組織移植術が開発され優れた成績が報告されている. そのうちでも血管柄付骨移植は現在最も頻用され成績 も良好な術式の一つである。しかしながら本法の大部 分は下肢応用例であり，上肢再建例の報告は比較的少 なく上肢再建への適応と問題点について確立した見解 は出されていないと思われる．今回自験例を分析し検 討を加えたので報告する.

\section{対 象と結 果}

上肢への血管柄付骨移植の応用例は 5 例で, 男性 1 例，女性 4 例であり，年粭は 27 才から 71 才，平均 50.2 才 であった。内訳は欠損性上腕骨偽関節 3 例，化膿性肘関 節炎による骨関節皮䖉欠損 1 例, 㳳骨末端部骨巨細胞腫 切除後の骨皮膚欠損 1 例であった，骨欠損の大きさは 3 $\mathrm{cm}$ から $13 \mathrm{~cm}$, 平均 $7.8 \mathrm{~cm}$ であった. 移植骨には血管柄付
腓骨 4 例と血管柄付腓骨頭 1 例を用いたが, 長さは $8 \mathrm{~cm}$ から $15 \mathrm{~cm}$ で平均 $12.6 \mathrm{~cm}$ であった。骨接合は screwの みによる固定が 4 例で，1例は screw と wire を併用 した，皮䖉欠損合併例は 2 例のみであったが，モニター 皮弁も含めて全例に同時皮弁移行を行った。

経過観察期間は 6 力月から 30 力月, 平均 12.8 力月で あるが，皮弁は全例とも完全生着した，骨瘾合は骨接 合部での骨折と離解を生じた 1 例を除き，中枢側は術 後 2 力月から 3 力月, 末梢側は 2 力月から 3.5 力月以内 の早期に得られた。ただし，移植骨の肥大は，現時点 では 1 例のみにしか認められていない. 合併症として は移植骨の骨折 1 例とごく軽度の採骨側足趾の阻血性 変形 1 例がみられたにすぎなかった（表 1 ).

\section{症例}

代表的症例を供覧する.

症例 1 ：M.O. 55才, 女性.

他医にて 2 度にわたりプレートによる短縮骨接合術 


\begin{tabular}{|c|c|c|c|c|c|c|c|c|c|c|c|c|c|c|c|}
\hline No. & Name & Age & Sex & Diagnosis & $\begin{array}{l}\text { Recipient } \\
\text { site }\end{array}$ & $\begin{array}{r}\text { Bone } \\
\text { defect } \\
(\mathrm{cm})\end{array}$ & $\begin{array}{r}\text { Graft } \\
\text { length } \\
(\mathrm{cm})\end{array}$ & $\begin{array}{l}\text { Internal } \\
\text { fixation }\end{array}$ & $\begin{array}{c}1 \\
\text { Skin } \\
\text { defect }\end{array}$ & $\underset{\substack{(\mathrm{mos}) \\
\text { Follow-up }}}{ }$ & $\begin{array}{l}\text { Bone union } \\
\text { proximal }\end{array}$ & $\begin{array}{l}\text { (mos) } \\
\text { distal }\end{array}$ & $\begin{array}{c}\text { Simultaneous } \\
\text { skin flap transfer }\end{array}$ & Complication & $\begin{array}{l}\text { enlargement } \\
\text { of the graft }\end{array}$ \\
\hline (1). & M.O. & 55 & $\mathrm{~F}$ & Pseudo Arthrosis & $\begin{array}{c}\text { Humerus } \\
\text { (supracondylar) }\end{array}$ & 5 & 9 & Screw & $(-)$ & 30 & 2.5 & 3.5 & Complete survival & non & $(+)$ \\
\hline (2)* & Y.N. & 35 & $\mathrm{~F}$ & Giant Cell Tumor & $\begin{array}{c}\text { Radius } \\
\text { (end) }\end{array}$ & 13 & 15 & Screw & $(+)$ & 11 & 3 & $-*$ & Complete survival & non & $(-)$ \\
\hline (3) & M.F. & 63 & $\mathrm{~F}$ & Pyogenic Arthritis & Elbow & 10 & 18 & $\begin{array}{l}\text { Screw } \\
\text { wire }\end{array}$ & $(+)$ & 11 & $6 * *$ & 2 & Complete survival & $\begin{array}{l}\text { fracture of } \\
\text { the graft }\end{array}$ & $(-)$ \\
\hline (4) & A.T. & 27 & M & Pseudo Arthrosis & $\begin{array}{c}\text { Humerus } \\
\text { (shaft) }\end{array}$ & 8 & 13 & Screw & $(-)$ & 6 & 2 & 3 & Complete survival & $\begin{array}{l}\text { toe deformity } \\
\text { (mild) }\end{array}$ & $(-)$ \\
\hline (5) & S.N. & 71 & $\mathrm{~F}$ & $"$ & $\begin{array}{l}\text { Humerus } \\
\text { (surgical neck) }\end{array}$ & 3 & 8 & Screw & $(-)$ & 6 & 2 & 3 & Complete survival & non & $(-)$ \\
\hline
\end{tabular}

* fibula head transplant

$* *$ fracture of the proximal end of the graft

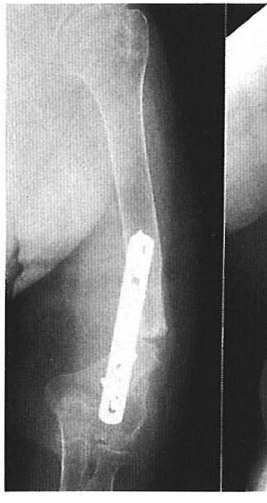

(a)

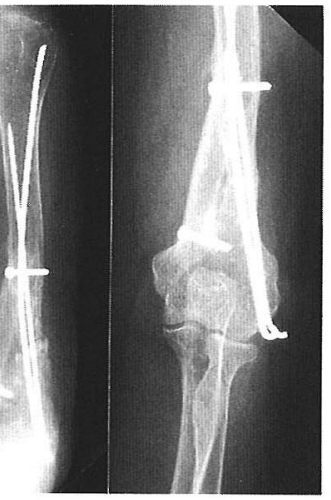

(b)

(c)

图 1 症例 1.M. O. 55才, 女性. 左上腕骨顆上部偽関節。
(a) 術前
(b) 術後 3.5 力月
(c) 術後 2 年 5 力月

をうけたが骨癒合の得られながった左上腕骨顆上部偽 関節例で，健側と比べ約 $5 \mathrm{~cm} の$ 骨短縮を生じていた。 これ以上の骨短縮を避けるため偽関節部を新鮮化して 間に腸骨片をつめ, さらに $9 \mathrm{~cm}$ 長の血管柄付腓骨の onlay graft を行った，術後 2.5 力月で中枢側の骨癒合 が得られ，術後3.5力月で末梢側の骨療合が得られた。 術後 2 年 5 力月の現在, 骨㙩合は強固で多少ではある が移植腓骨の肥大が認められる(図 1 ).

症例 2 : Y.N. 35才, 女性.

右暁骨遠位端部骨巨細胞腫例であり，暁骨遠位端部 を手関節面を含めて広範切除し血管柄付腓骨頭移植に て再建した。術後 3 力月で骨接合部の骨瘾合が得られ， 術後10力月の現在, 手関節面の適合性は比較的良好で

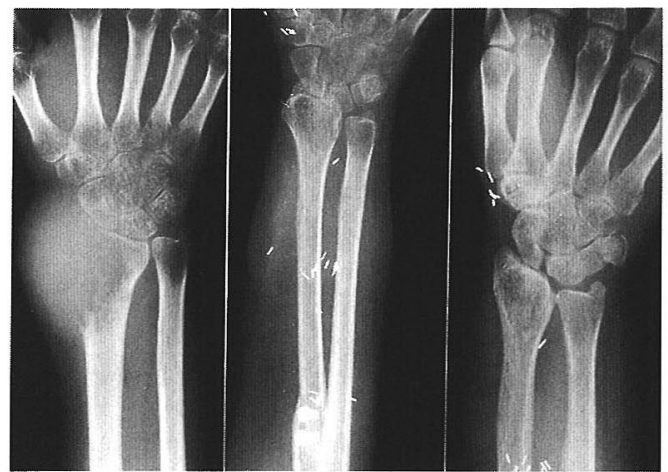

(a)

(b)

(c)

图 2

症例 2.Y.N. 35才，女性。 右暁骨遠位端部骨巨細胞腫

(a) 術前

(b) 術後 3 力月

(c) 術後10力月

関節裂隙も保たれており，疼痛なく屈曲 $10^{\circ}$, 伸展 $40^{\circ}$ まで可能となっている.

\section{考察}

下肢再建において血管柄付骨移植は骨欠損の大きい 症例や難治性偽関節，骨皮虑欠損合併例，感染を合併 した骨欠損に応用され優れた成績が報告されているが， 上肢再建においても，こういった症例は血管柄付骨移 植のよい適応と考えられる。また，関節面を含む楛骨 遠位端欠損には，形態面の類似性と関節軟骨温存によ る良好な手関節機能獲得の立場より血管柄付腓骨頭移 植がよい適応であろう。さらに, Weiland らは小児の 早期骨端線閉鎖を血管柄付腓骨頭移植で再建しており, 
手技や予後などについて確立した見解は出されていな いが，他に決定的な治療法がない現在，検討すべき方 法と思われる.

問題点としては，上肢においては受骨部や骨欠損の 小さい症例が多く，ことに手関節より遠位では血管柄 付腓骨や血管柄付腸骨では大きすぎて適用が困難な場 合があることである．このような症例には血管柄付中 足骨移植や著者の報告した薄骨皮質付血管柄付骨膜移 植で再建可能なものも多く考慮すべきと思われる。い ずれにしても，各移植方法の特徴を熟知して needsに 応じて選択利用することが大切と思われる。このほか に注意すべき点としては，血管柄付骨移植は血行温存 のため内固定の部位が狭く限定されるうえに，上肢応 用例においては受骨部が小さく細くて強固な固定がな かなか困難なことが多いことで, 固定方法については 術前に十分検討しておく必要があると思われる。また， 10才以下の小児においては腓骨採取後に足関節の外反 変形をきたしやすく，これを予防するため必ず脛腓間 固定を行っておくことも忘れてはならないと考えている.

\section{ま と め}

1. 血管柄付骨移植の上肢応用 5 例を報告した.

2 . 上肢骨欠損に対し欠損が大きい場合や難治例，皮 虑欠損や感染合併例は血管柄付骨移植のよい適応で良 好な結果を期待できる.

3. 関節面を含む㳳骨末端欠損には血管柄付腓骨頭移 植がよい適応である.

4. 上肢では骨欠損や受骨部が小さく, 血管柄付腓骨 移植や血管柄付腸骨移植の適用が困難な症例も多いが, かかる場合には血管柄付中足骨移植や薄骨皮質付血管 柄付骨膜移植を考虑すべきである。

\section{参 考 文 献}

1）土井一輝 - 他：遊離血管柄付骨移植の臨床応用一外 傷性下腿骨欠損に対して一. 日災医誌, $28 ： 312-319$, 1980.

2) Pho, R.W.H.: Malignant Giant-Cell Tumor of the Distal End of the Radius Treated by a Free Vascularized Fibular Transplant. J.Bone Joint Surg, 63-A : 877-884, 1981.

3）酒井和裕 - 他：上肢の偽関節に対する血管柄付骨 骨膜移植の応用. 日手会誌，5：698-704，1988.

4) Weiland, A.J. et al.: Vascularized Bone Grafts in the Upper Extremity. In Serafin, D., and Buncki, H. J.: Microsurgical Composite Tissue Transplantation. Mosby, St. Louis, 605-625, 1979.

\section{質 問 長崎大学 今村広太郎}

移植腓骨の内固定には苦労することが多いと思いま すが，何か良い方法がありますか？

\section{解 答的裕}

上腕骨の固定に関しては，頝部では骨頭内に腓骨の 断端を择入して screw で固定，骨幹部では骨溝を作成 して挿入し断端を screw で固定，顆上部では onlay にして断端を screw で固定している。

追 加熊本整形外科病院 田嶋 光 肘の関節部欠損例の再建に対しては第 1 足趾 MP 関 節の移植の法もある.

\section{解 答和裕}

先生の御指摘の方法も症例によっては用いられるべ きと思いますが，症例 3 に関しては，筋腱の欠損を合 併していたこと，骨欠損が大きいこと，ドナーの機能 障害を防ぎたいことより血管柄付骨移植を選択した. 